\title{
Integrated livestock and oil palm plantation as sustainable agricultural bioindustry in Bangka Island, Indonesia
}

\author{
Suyatno $^{1 *}$, Zikril Hidayat ${ }^{1}$, Suharyanto ${ }^{1}$, and Wahyu Wibawa $^{2}$ \\ ${ }^{1}$ Bangka Belitung Assessment Institute for Agricultural Technology, Jl. Mentok km.4 Pangkalpinang, \\ 33134, Indonesia \\ ${ }^{2}$ West Sumatera Assessment Institute for Agricultural Technology, J1. Padang-Solok KM. 40 Padang, \\ West Sumatera 25168
}

\begin{abstract}
As an emerging economic sector, agriculture in the Province of Bangka Belitung has less contribution both in terms of production and contribution towards farmer's income. Therefore, the implementation of sustainable agriculture by integrating crops and livestock is argued to increase the competitiveness of agricultural products and farmer's income. Based on local resources, one of the sustainable agricultural applications that can be implemented in Bangka Belitung is bio-industrial agriculture by integrating oil palm, citronella, and cattle farming to optimize marginal land. The concept of the bio-industrial agriculture model in this project contained several aspects i.e., environmentally friendly, effective and efficient, competitive, and profitable. The model implemented in the farmer groups increased farmer's income from oil palm plantations and beef cattle. This was due to an increase in the productivity of Bali cattle with an average daily gain (ADG) of $0.22 \mathrm{~kg}$ to $0.56 \mathrm{~kg}$, also an increase in the production of fresh fruit bunches (FFB) of oil palm. In general, the model of oil palm-cattle integration is suitable for sustainable agricultural development in Bangka Belitung.
\end{abstract}

\section{Introduction}

Bangka Belitung archipelago is a province located to the east of the island of Sumatra, Indonesia. In this province the agricultural sector plays an important role to the economic growth. This can be seen from the contribution of the agricultural sector to the GRDP of the Bangka Belitung Province in 2017 of $18.16 \%$, higher than the mining sector which was only $13.26 \%$ [1].This sector is only rivaled by the industrial sector (especially the tin mining industry) which is also the mainstay of the people's economy. However, by the year the agricultural sector continues to experience growth in line with the decreasing contribution of the mining sector. As an archipelago where economy was originally based on mining, the demand for food is mostly supplied from other islands around it such as Sumatra and Java. This makes Bangka Belitung a province with a low Food Security Index, which is only 56.03

\footnotetext{
* Corresponding author: suyatno.spt@pertanian.go.id
} 
and ranks 29th out of 34 provinces in Indonesia [2]. As well as rice as the staple food, most of the need for animal protein, especially beef is supplied from Lampung and South Sumatra.

The development of the agricultural sector in Bangka Belitung continues to be accelerated in order to anticipate the diminishing role of industry, especially the tin mining industry whose deposits are decreasing. Nevertheless, the production and contribution of the agricultural sector to farmer's income in Bangka Belitung Province is still low. This is due to several factors, such as: 1) low levels of soil fertility, 2) the transition period from mining communities to agricultural communities, 3) land ownership problems which is still not optimally utilized, 4) the marketing chain is not well established.

Therefore, the implementation of sustainable agriculture with the integration of crops and livestock is suitable to be applied in Bangka Belitung as an effort to increase the competitiveness of agricultural products and increase farmer's income. Based on the local resources, one of the sustainable agricultural applications that has the potential to be applied in the Province of the Bangka Belitung is bio-industrial agriculture by integrating oil palm, citronella, and cattle farming in order to optimize marginal land. Oil palm is one of the estate crop commodities that many farmers grow for their livelihood. Its value has been highly relied on to increase the Local Government Generated-Revenue of Bangka Belitung.

Crude palm oil (CPO) is the main product of palm oil industry, while the by-products that have high economic value are Palm Kernel Expeller (PKE), empty fruit bunches (EFB), palm pressed fibres (PPF), and shells [3]. PKE can be used as feed for cattle [4] and broiler chicken [5]. However, the palm oil by-product in Bangka Belitung has not been utilized optimally. On the other hand, the limited of animal feed, especially for ruminants in the dry season still became a problem for livestock development in Bangka Belitung. Palm oil plantation also produced several types of biomasses including oil palm fronds (OPF), oil palm trunks (OPT), oil palm bark (OPB) [6]. The OPF can be used as forage for ruminants such as sheep, goat and cattle [7]. Thus, integration of palm oil plantation and cattle will benefit for both commodities in a way that manure from cattle is used as organic fertilizer to increase soil.

As previously mentioned, land in Bangka Belitung is dominated by ex-mining land that lacks nutrients for plants. Hence, it is also necessary to develop plants that have high adaptability to optimize marginal land use in Bangka Belitung. Citronella grass (Cymbopogon nardus L.) have a strong viability, and are often used in marginal areas. Citronella grass can live in extreme conditions such as nutrient-poor soils, alkaline soils, steep slopes, and can be integrated with other plantation crops. The roots are able to hold the soil so that it is widely recommended as a plant to prevent erosion [8]. Citronella grass is one type of essential oil-producing plant. The results of the distillation of the leaves produced essential oil which is known as Citronella oil. Citronella grass distillation produces essential oil and waste in the form of residual biomass. This residual biomass has the potential to be used as a source of fibre for cattle as a substitute for grass. So that the integration of oil palm, lemongrass and livestock is potential to create agricultural bioindustry that encompass several aspects i.e., environmentally friendly, effective and efficient, competitiveness, and profitable. The aim of this study was to evaluate the implementation of oil palm, lemongrass and livestock integrated farming model in the concept of sustainable bio-industrial agriculture at Bangka Island.

\section{Methods}

\subsection{Study area}

This project was conducted at the Petaling Experimental Station in Pangkalpinang; Semoga Jaya Farmers Group, Lubuk Besar District, Central Bangka Regency; and in the Tunas Baru 
Farmer Group, Sungai Selan District, Central Bangka Regency. Time period for doing this study was from January 2015 to December 2019. All locations were in Bangka Island, Bangka Belitung Province, Indonesia. This island is bordered by the South China Sea to the north, Belitung Island to the east and the Java Sea to the south.

\subsection{Data and Variables}

Farm level data were collected from three locations including Petaling Experimental Station in pangkalpinang; Semoga Jaya Farmers Group, Lubuk Besar District, Central Bangka Regency; and in the Tunas Baru Farmer Group, Sungai Selan District, Central Bangka Regency. Data were collected from primary and secondary sources. The primary data were obtained through the use of questionnaire, interview, and personal observation. The secondary source data were collected by desk study from local government, statistical agency, research reports, seminar papers, internet and other relevant literature. Data collected include input and output for crop and livestock, production for each commodity, and socioeconomic. Farmer's net income is calculated using "cost and income analysis" as follows:

Where:

$$
\begin{aligned}
& N R=T R-T C \\
& T R=T p \times P \\
& T C=F C+V C
\end{aligned}
$$

$$
\begin{aligned}
& \mathrm{NR}=\text { Net Revenue } \\
& \mathrm{TR}=\text { Total Revenue } \\
& \mathrm{TC}=\text { Total Cost } \\
& \mathrm{Tp}=\text { Total Product } \\
& \mathrm{P}=\text { Price } \\
& \mathrm{FC}=\text { Fixed Cost } \\
& \mathrm{VC}=\text { Variable Cost }
\end{aligned}
$$

The result of farmer's income in integrated and non-integrated farming model then compared to know the effectiveness of the integrated farming model.

\section{Results and discussion}

\subsection{Characteristic of selected study area}

\subsubsection{Semoga Jaya Farmer Group}

Semoga Jaya Farmers Group is located in Lubuk Besar Village, Lubuk Besar District, Central Bangka Regency, Bangka Island of Bangka Belitung Province. Semoga Jaya farmer group is the first farmer group in Bangka Island that implementing integrated bio-industrial agriculture model between oil palm, citronella grass and livestock. Semoga Jaya farmer group had 12 of beef cattle that raised in the cowshed located in the oil palm plantation.

\subsubsection{Petaling Experimental Station}

Petaling Ex-farm is located in the back yard of the Assessment Institute for Agricultural Technology (AIAT) office with dry climate lowland agroecosystem. The area of Petaling exfarm is 26.2 hectares. Various collections of germplasm found in Petaling ex-farm including durian, pepper, cassava, pineapple, taro and merawang chicken. Besides of cattle (Bali and 
PO cattle) Petaling ex-farm also has a collection of Boerka goats. To support livestock development, Petaling ex-farm also collects various forages and superior grasses. Some of estate commodities such as pepper, oil palm, coffee, oranges and rubber are also grown at Petaling ex-farm. Integrated bio-industrial agriculture model between oil palm, citronella grass and livestock is also located in Petaling ex-farm. This model are equipped with citronella oil refining plant and biogas production.

\subsubsection{Tunas Baru Farmer Group}

Tunas Baru farmer group is located in Sungai Selan Village, Sungai Selan District, Central Bangka Regency, Bangka Island of Bangka Belitung Province. Tunas Baru Farmer Group was established on January 11, 2012. When it was founded the farmer group only focus on oil palm plantations. As the implementation of local government program, Tunas Baru farmer group received 25 heads of cattle in 2013. Number of cattle continued to increase to reach about 35 heads in 2015. Starting from 2015, The Tunas Baru Farmer Group has been implementing the integration of livestock and oil palm plantation under supervision by AIAT Bangka Belitung and Indonesian Center for Animal Research and Development (ICARD). The Tunas Baru Farmer Group as a farmer group that succeeded in implementing palm-cow integration in 2019 has a population of 217 cows distributed across all members, with compost production on average of 5-7 tons per month, and the area of oil palm plantations for all members is around 40 ha.

\subsection{Linking crop and livestock at the farm level}

Integrated bio-industrial agriculture model between oil palm, citronella grass, and livestock is expected to be a pilot of bio-industrial agriculture for farmers in the Bangka Belitung Islands. Livestock can provide organic materials, both solid (manure) and liquid (urine), which are needed to maintain soil fertility and health to support the growth of oil palm and citronella. Meanwhile, biomass from plants and by-products of the oil palm industry can be used as animal feed (Figure 1). Citronella grass on the sidelines of oil palm plantations at Semoga Jaya Farmer Group and Petaling Experimental Station is presented in Figure 2.

Oil palm has abundant biomass potential as a source of animal feed both from plantations and from palm oil mills. The by-product of plantations commonly used as ruminant feed is Oil Palm Front (OPF) [9]. OPF is obtained from both planting and pruning activities. One OPF consists of approximately 100 leaflets, one rachis, and one petiole [10] . On average, each oil palm tree produces $22 \mathrm{OPF} /$ year. OPF contain $31.1 \%$ of dry matter and $4.2 \%$ crude protein $[11,12]$. One hectare of productive oil palm plantation can produce 2,3 tons of dry matter per year from OPF [13]. This data showed that OPF has the potential for the replacement of native grass as forage for ruminant continuously throughout the year.

We compare the income of integrated oil palm farmers and non-integrated farmers. In the Integration system, the feed given is $60 \%$ OPF and $40 \%$ PKE as fermented feed. While for non-integration, cows are given $100 \%$ grass as forage. The integration model increased the productivity of Bali cattle, with an average daily gain (ADG) of $0.56 \mathrm{~kg}$ (Table 1). This also led to the improvement of farmers' income from cattle farming from IDR 268,005 to IDR 881,262 . The integration model caused farmer more effective to manage the feed. OPF was obtained from pruning activities when harvesting oil palm fruit every week. Then farmers processed OPF from chopping, blending, and fermenting once a week. This procees is a method to improve OPF digestibility [14]. In the conventional model, the farmer cut and carry the grass every day to fed their cattle. The use of agriculture by-product including OPF as livestock feed will reduce the feeding cost of the livestock industry[15] and reduce the number of labor used. 


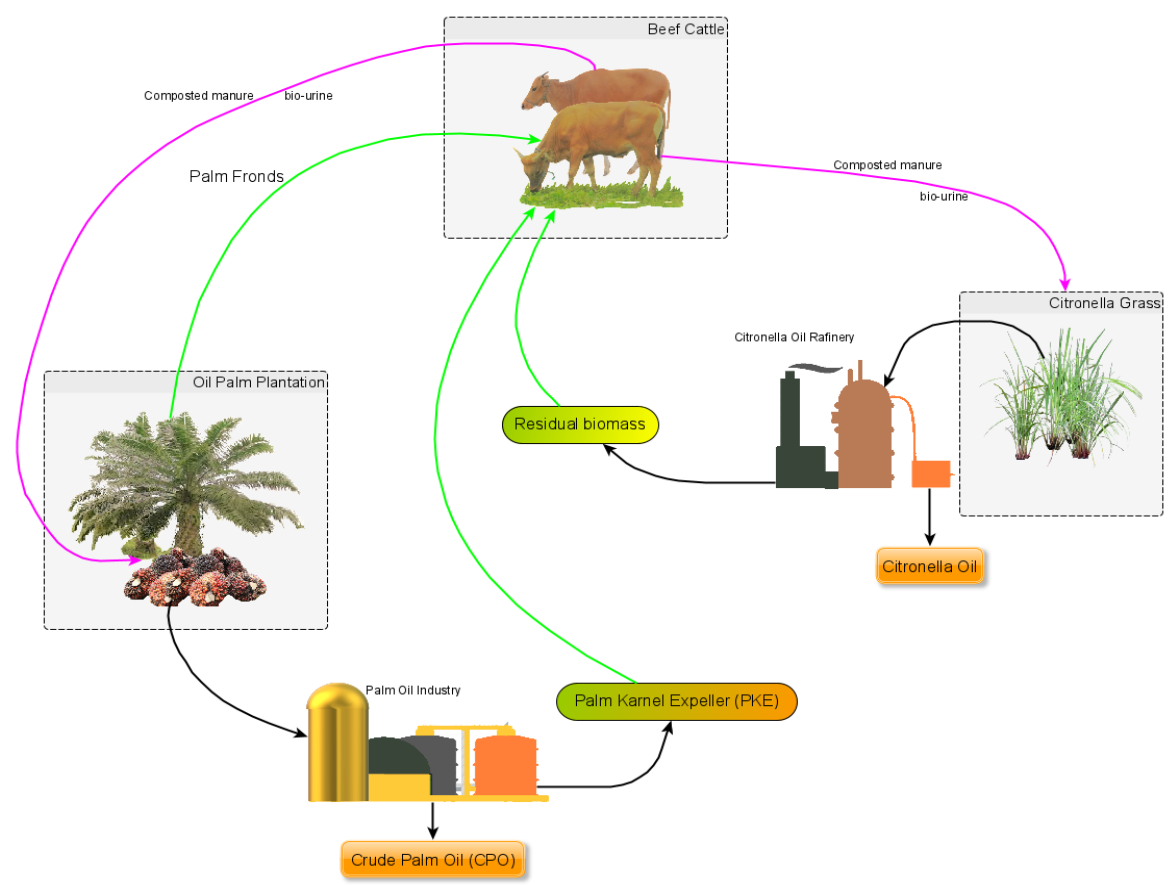

Fig. 1. Integrated bio-industrial agriculture model between oil palm, citronella grass and livestock

Table 1. Comparison of farmers' income in integrated and non-integrated systems

\begin{tabular}{|c|c|c|}
\hline Items & \multicolumn{2}{|c|}{ Treatment } \\
\hline Farmer income from oil palm & $\begin{array}{l}\text { Without Organic } \\
\text { Fertilizer }\end{array}$ & $\begin{array}{c}\text { Organic Fertilizer } \\
(20 \mathrm{~kg} / \text { tree/month of } \\
\text { manure and } 4 \text { litre of } \\
\text { urine/tree/month })\end{array}$ \\
\hline FFB production (ton/ha/month) & 4.76 & 6.14 \\
\hline FFB price (IDR/kg) & 733,33 & 733,33 \\
\hline Total revenue (IDR/month) & $2,984,608$ & $4,500,173$ \\
\hline $\begin{array}{l}\text { Cost for organic fertilizer } \\
\text { (IDR/month) }\end{array}$ & 0 & 1.230 .000 \\
\hline Net Revenue (IDR/month) & 2.984 .608 & 3.270 .173 \\
\hline Farmer income from cattle & $\begin{array}{l}\text { Conventional of } \\
100 \% \text { grass as } \\
\text { feed }\end{array}$ & $\begin{array}{c}\text { Integration with } 60 \% \text { of } \\
\text { OPF and } 40 \% \text { of PKE } \\
\text { as feed }\end{array}$ \\
\hline ADG (kg/day) & 0,22 & 0,56 \\
\hline Live cattle price (IDR/kg) & 58.000 & 58.000 \\
\hline Total Revenue (IDR/month/head) & 390.630 & 974.400 \\
\hline Net Revenue IDR/month/head) & 268.005 & 881.262 \\
\hline
\end{tabular}


a)

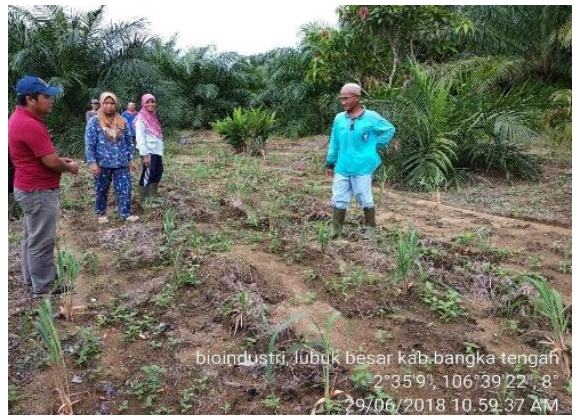

b)

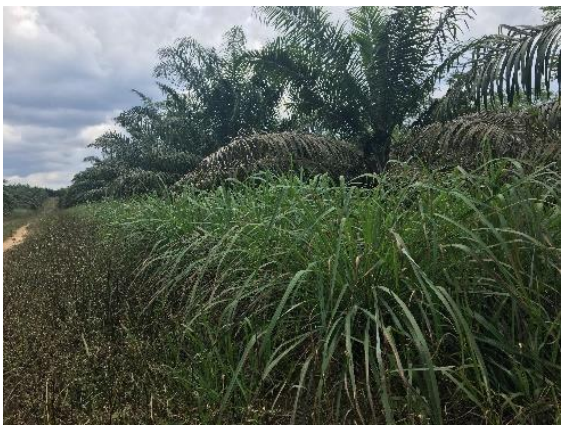

Fig. 2. Citronella grass on the sidelines of oil palm plantations at Semoga Jaya Farmer Group (a) and Petaling Experimental Station (b).

The integration model that was applied can also increase farmer's income from oil palm from IDR $2.98 \mathrm{million} / \mathrm{month}$ to IDR $3.27 \mathrm{million} / \mathrm{month}$. This was due to the farmer used organic fertilizer from livestock (manure and urine) that lead to the increase of productivity (Table 1). Urine from livestock has been reported can give positive effect to the growth of oil palm[16]. Another group of researcher also reported that livestock give several benefit to the palm oil plantation in integration system that lead to the improvement of farmers income in Malaysia. The details of contribution for each comodity on farmer income were FFB contributing $81 \%$, livestock $15 \%$, oil palm fronds (OPF) $3 \%$, and animal manure $0.03 \%$ [17].

In this study, citronella grass were planted in the space between oil palms to optimize the use of land. Citronella grass are suitable to be planted in fields with a light intensity range of between $75-100 \%$ [18]. Citronella grass is often used in marginal areas. Citronella grass is grown as a raw material in the distillation of citronella oil. As previously reported, production of fresh citronella leaves aged 2 years on average 30.62 tons/Ha/year if planted between oil palms, and 37.54 tons/Ha/year if planted in monoculture [19] . Citronella oil yield by steam distillation method at Petaling experimental station was $0,74-0,75 \%$ [19] and at Semoga Jaya farmer group Lubuk Besar was 0,74\% [20]. Based on the data of production and costs, the prospect of citronella grass farming in Bangka Belitung has an RC Ratio of 1.8 and a return on investment of 3.3 years [21].

Citronella grass refining produces citronella oil as main product, and produces a byproduct in the form of residual biomass. This biomass can be used as cattle feed, either given directly or processed as silage or hay. It has been studied that residual biomass from citronella oil refinery consist of $9.72 \%$ of protein and it is better than rice straw $(6.25 \%)$ that commonly used as feed in small holder farmer of Indonesia [22]. Residual biomass from citronella oil refinery in Petaling Experimental Station contains $6.82 \%$ crude protein, GE 3,891 kcal $/ \mathrm{kg}$, crude fiber $44.51 \%$, ash $7.25 \%$, and fat $1.41 \%$. The addition of residual biomass from citronella oil refinery into the ration resulted in ADG of Bali cattle in Petaling Experimental Station by $0.45 \mathrm{~kg}$ /day [19]. In 2019, we also recorded some of reproduction parameter for beef cattle in Petaling experimental station. Some parameter that observed were calving rate $(55 \%)$, calf crop $(38.46 \%)$, average male calf birth weight $(13.70 \mathrm{~kg})$, and average female calf birth weight $(10.67 \mathrm{~kg})$. This data shows that the performance of Bali cattle is still close to the average productivity of Bali cattle in several regions in Indonesia, even higher than West Nusa Tenggara in terms of calving rate (51.7\%) [23].

The model implemented both in Petaling Experimental Station and Semoga Jaya Farmer Groups was also equiped with biogas instalation. The benefits of biogas for rural households 
are healthier cooking, reducing wood fuel, and being environmentally friendly. However, due to the long distance between the cowshed and residential areas, biogas can only be used for the needs of fuel around the cowshed. Although small-scale biogas is suitable for rural areas, there are some obstacles to large-scale biogas development. These constraints include: lack of adequate information and technical support to households, policy implications, socioeconomic barriers including the low investment power of farmers, and non-existent institutional support [24].

\subsection{The Prospect of crop-livestock integrated farming in Bangka Belitung}

Integration of livestock-oil palm-citronella grass brought a positive impact towards the smallholder farmer's income. However, the application of this model should consider the existing resources. Under certain conditions, this model cannot be fully applied. Even though it was profitable, the investment cost of citronella distillation was too expensive for small farmers. The price of citronella oil for the Bangka Belitung region was also unstable. This was due to the market chain has not yet been formed. Partial the model that has the potential to be developed is the integration of oil palm and cattle.

The opportunity to increase beef cattle population accoding to the data in Table 2 was 129.937 animal unit (one animal unit is equal to one head of cattle). Although there was a $6.44 \%$ growth in the cattle population from 2019 to 2020 [25], there is still a great opportunity to increase the number of cattle in Bangka Belitung. Moreover, the same source of data shows that from 2019 to 2020 the area of oil palm plantations in Bangka Belitung grew 2.17\% [25]. The provincial government of Bangka Belitung has issued Governor Regulation No. 43 of 2019 concerning oil palm-cattle integration in oil palm plantation companies as one of the effort to increase beef cattle productivity. By this reagulation, the oil palm plantation companies in Bangka Belitung must rearing at least one beef cattle/10 ha of plantation area or maximum two beef cattle/ha of plantation area [27]. This regulation is important to improve food security in Bangka Belitung in line with previous research that the development of a modern integrated farming system can improve food security and environmental sustainability [28,29].

Table 2. The Estimated Carrying Capacity from Oil Palm Frond (OPF) biomass of Oil Palm Plantation in Bangka Belitung for Beef Cattle Development in 2020

\begin{tabular}{|l|r|r|r|r|r|}
\hline District/City & \multicolumn{1}{|c|}{$\begin{array}{c}\text { Area of palm } \\
\text { plantation } \\
\text { (ha)* }\end{array}$} & $\begin{array}{c}\text { Estimated } \\
\text { OPF dry } \\
\text { matter } \\
\text { (ton/year)** }\end{array}$ & $\begin{array}{c}\text { Existing beef } \\
\text { cattle } \\
\text { population } \\
\text { (animal unit)* }\end{array}$ & $\begin{array}{r}\text { Carrying } \\
\text { capacity } \\
\text { (animal } \\
\text { unit)*** }\end{array}$ & $\begin{array}{c}\text { Opportunity } \\
\text { to increase } \\
\text { capacity } \\
\text { (animal } \\
\text { unit) }\end{array}$ \\
\hline Bangka & 11.591 & 26.660 & 1.498 & 23.386 & 21.888 \\
\hline Belitung & 5.839 & 13.429 & 1.800 & 11.780 & 9.980 \\
\hline West Bangka & 18.407 & 42.336 & 1.886 & 37.137 & 35.251 \\
\hline Central Bangka & 9.352 & 21.510 & 5.567 & 18.868 & 13.301 \\
\hline South Bangka & 21.560 & 49.588 & 1.896 & 43.498 & 41.602 \\
\hline East Belitung & 5.457 & 12.551 & 1.646 & 11.010 & 9.364 \\
\hline Pangkalpinang & 0 & 0 & 1.449 & 0 & -1.449 \\
\hline Total & 72.206 & 166.074 & 15.742 & 145.679 & 129.937 \\
\hline
\end{tabular}

* $\quad$ Data obtained from Bangka Belitung Statistical Agency [25]

** $\quad$ Estimated dry matter[13]

*** Estimated carrying capacity [26] 


\section{Conclusion}

The crop-livestock integration model in this project can also increase farmer's income and farmer's competitiveness. The model implemented in the farmer groups can increase farmer's income from oil palm plantations and beef cattle. However, the decision to extend this model must be consistent with developments and trends in the local and community of agricultural sector and available resources. In general, the partial model of oil palm-cattle integration is suitable for sustainable development in Bangka Belitung.

\section{References}

1. BPS-Statistics of Kepulauan Bangka Belitung Province, Kepulauan Bangka Belitung Province in Figures 2017 (BPS-Statistics of Kepulauan Bangka Belitung Province, Pangkalpinang, (2017)

2. Food Security Agency of the Ministry of Agriculture of the Indonesia, Food Security Index of Indonesia 2019 (2019)

3. Y. A. Tan, OCL - Oleagineux Corps Gras Lipides 13, 9 (2006)

4. J. D. V. van Wyngaard, R. Meeske, and L. J. Erasmus, Animal Feed Science and Technology 199, 29 (2015)

5. P. Saenphoom, J. B. Liang, Y. W. Ho, T. C. Loh, and M. Rosfarizan, Asian-Australasian Journal of Animal Sciences 26, 537 (2013)

6. M. Vakili, M. Rafatullah, M. H. Ibrahim, B. Salamatinia, Z. Gholami, and H. M. Zwain, Environment, Development and Sustainability 17, 691 (2015)

7. M. Ebrahimi, M. A. Rajion, Y. M. Goh, and A. Q. Sazili, Journal of Animal Physiology and Animal Nutrition 96, 962 (2012)

8. P. P. Adhikary, H. C. Hombegowda, D. Barman, and M. Madhu, International Journal of Sediment Research 33, 340 (2018)

9. I. Dahlan, Oil Palm Frond, a Feed for Herbivores (2000)

10. E. Hambali and M. Rivai, in IOP Conference Series: Earth and Environmental Science (Institute of Physics Publishing, 2017), p. 012050

11. M. Ishida and O. Abu Hassan, Utilization of Oil Palm Frond as Cattle Feed (n.d.)

12. M. Wan Zahari, O. Abu Hassan, H. K. Wong, and J. B. Liang, Asian-Australasian Journal of Animal Sciences 16, 625 (2003)

13. K. Diwyanto, D. M. Sitompul, I. Manti, I.-W. Mathius, and Soentoro, in Lokakarya Sistem Integrasi Kelapa Sawit-Sapi, pp. 11-22 (2002)

14. S. Mookiah, W. N. Wan Mohamed, 'Abidah Md Noh, N. A. Ibrahim, M. A. Fuat, S. K. Ramiah, E. L. Teik Chung, and N. L. H. Mat Dian, Asian-Australasian Journal of Animal Sciences (2020)

15. M. A. Azmi, M. T. Yusof, Z. Zunita, and H. A. Hassim, in IOP Conference Series: Earth and Environmental Science (Institute of Physics Publishing, 2019), p. 012077

16. B. Alvi, M. Ariyanti, and Y. Maxiselly, Kultivasi 17, 622 (2018)

17. B. H. Gabdo and I. bin Abdlatif, Journal of Agricultural Science 5, (2013)

18. M. Sukamto and D. Suheryadi, in Prosiding Seminar Nasional Inovasi Perkebunan (Pusat Penelitian dan Pengembangan Perkebunan, Bogor, 2011), pp. 175-180

19. Rubiyo, H. Zikril, H. Rahmat, Nuraini, and Ahmadi, Laporan Akhir Model Bioindustri Lada, Serai Wangi Dan Ternak Terpadu Di Kepulauan Bangka Belitung (Pangkalpinang, (2016)

20. W. Wahyu, H. Zikril, Nuraini, S. Mamik, and Ahmadi, Laporan Tengah Tahun Model Sistem Pertanian Bioindustri Spesifik Lokasi Di Kepulauan Bangka Belitung (Pangkalpinang, (2017) 
21. Nuraini, H. Zikril, Rubiyo, and H. Rahmat, in Pertanian Bioindustri Solusi Pertanian Masa Depan, edited by H. Lintje, Rubiyo, and H. Rachmat (IAARD PRESS, Jakarta, pp. 153-165 (2018)

22. R. Manurung, Y. Abduh, A. W. Uin, S. Gunung, D. Bandung, I. Sugoro, B. Tenaga, and N. Nasional, Article in Pakistan Journal of Nutrition (2015)

23. H. Martojo, Reproduction in Domestic Animals 47, 10 (2012)

24. H. Roubík and J. Mazancová, Environmental Development 33, 100505 (2020)

25. BPS-Statistics of Kepulauan Bangka Belitung Province, Kepulauan Bangka Belitung Province in Figures 2021 (BPS-Statistics of Kepulauan Bangka Belitung Province, Pangkalpinang, 2021)

26. A. Thahar and P. Mahyuddin, in ACIAR Monograph Series: Draught Animal Systems and Management: An Indonesian Study, edited by T. E., C. R.S.F., and H. D., 19th ed. (Australian Centre for International Agricultural Research, Canberra, 1993)

27. Pemerintah Provinsi Kepulauan Bangka Belitung, Peraturan Gubernur Nomor 43 Tentang Integrasi Usaha Sawit-Sapi Pada Perusahaan Perkebunan Kelapa Sawit Di Provinsi Kepulauan Bangka Belitung (Pangkalpinang, 2019)

28. G. Lemaire, A. Franzluebbers, P. C. de F. Carvalho, and B. Dedieu, Agriculture, Ecosystems and Environment 190, 4 (2014)

29. M. Moraine, M. Duru, P. Nicholas, and O. Therond, (2014) 